\title{
Contrapublicidad en la CiUdad DEL CONSUMO. SUbVIRTIENDO EL SENTIDO EN LA PIEL DEL ASFALTO
}

Counter-Advertising in the City of Consumerism. Subverting the Sense in the Asphalt Skin

\section{Ximo González Marí \\ ximglez@gmail.com \\ Filólogo}

RESUMEN: La sociedad del consumo determina las condiciones sociales en la Postmodernidad. La ciudad, configurada como un espacio de tránsito sin identidad ni historia, está definida como una continua reconfiguración de sí misma. Una ciudad convertida en mera fachada, en un escaparate de múltiples estímulos que cambian rápidamente para seducir al ciudadano relegado al papel de consumidor. Desde esta posición, el sujeto deberá construir alternativas que posibiliten un papel actante en la eterna reformulación que caracteriza la ciudad como suceso y no como espacio. En estos espacios para el consumo sobre el que se proyectan las ciudades postmodernas, recreadas como verdaderos centros comerciales, el ciudadano debe encontrar su propia voz como sujeto transformador de la sociedad. Daremos fe del potencial creativo y renovador de los espacios del consumo de masas, convertido en el nuevo campo social de encuentro y enunciación. Veremos cómo los movimientos activistas se apropian del lenguaje publicitario que configura el discurso urbano para subvertirlo y, mediante la tergiversación y la parodia, desenmascarar el vacío y miseria moral que la lógica mercantilista trata de esconder. De este modo, evidenciaremos el potencial creativo en estas prácticas contraculturales que ocupan los espacios públicos y los templos del consumo para expresar su crítica a una sociedad construida para el consumo. Los culture jammers o piratas publicitarios, mediante la técnica de guerrilla contrapublicitaria, ocupan los espacios de visibilización consumista antes monopolizados por las corporaciones, como vallas publicitarias o anuncios, para difundir su mensaje. Utilizarán el distanciamiento y el humor para, a través del collage y el montaje, difundir su mensaje de forma visual e impactante. En consecuencia, surgirán nuevos significados que contradicen el discurso del consumo que domina las 
ciudades y construyen una crítica a la ciudad desde el centro mismo de los espacios mediatizados por el mercado.

Palabras ClaVe: contra-publicidad, no-lugar, culture jamming, consumo.

ABSTRACT: The consumer society determines social conditions in the postmodern era. The city, configured as a space of transit with no identity or history, is defined as a continuous reconfiguration of itself. It has been turned into a mere facade, a showcase of multiple, rapidly-changing stimuli to seduce the citizen, now relegated to the role of consumer. From this position, subjects must construct alternatives that give them an active role in the eternal reformulation that characterizes the city as an event and not as a space. In these spaces for consumerism that postmodern cities have become, recreated as authentic shopping malls, citizens must find their own voices as transformers of society. In this paper we show the potential for creativity and renewal that these spaces of mass consumption possess, spaces that have become the new social terrain for encounter and enunciation. We will see how activist movements appropriate the language of advertising that shapes urban discourse, to subvert it and, through misrepresentation and parody, unmask the vacuum and moral paucity that mercantilism tries to hide. In this way, we highlight the creative potential in these counter-cultural practices that occupy public spaces and temples of consumption to express their criticism of a purpose-built consumer society. Culture jammers, using the guerrilla technique of counter-advertising, occupy the spaces of consumerist visibility monopolized by corporations, such as billboards or advertisements, to spread their message. They use detachment and humour, through collage and editing, in a visual and impactful way, giving new meanings that contradict the dominant discourse of consumption in the cities and construct a critique of the city from the centre of the spaces mediated by the market.

KEYWORDS: counter-advertising, non-place, culture jamming, consumerism. 
RESUM: La societat del consum determina les condicions socials en la Postmodernitat. La ciutat, configurada com un espai de trànsit sense identitat ni història, està definida com una contínua reconfiguració de si mateixa. Una ciutat convertida en simple façana, en un aparador de múltiples estímuls que canvien ràpidament per seduir al ciutadà relegat al paper de consumidor. Des d'aquesta posició, el subjecte haurà de construir alternatives que possibiliten un paper actant en l'eterna reformulació que caracteritza la ciutat com succés i no com a espai. En aquests espais per al consum sobre el qual es projecten les ciutats postmodernes, recreades com a veritables centres comercials, el ciutadà ha de trobar la seva pròpia veu com a subjecte transformador de la societat. Donarem fe del potencial creatiu i renovador dels espais del consum de masses, convertit en el nou camp social de trobada i enunciació. Veurem com els moviments activistes s'apropien del llenguatge publicitari que configura el discurs urbà per subvertir-lo i, mitjançant la tergiversació i la paròdia, desemmascarar el buit i misèria moral que la lògica mercantilista tracta d'amagar. D'aquesta manera, evidenciarem el potencial creatiu en aquestes pràctiques contraculturals que ocupen els espais públics i els temples del consum per expressar la seva crítica cap a una societat construïda per al consum. Els culture jammers o pirates publicitaris, mitjançant la tècnica de guerrilla contrapublicitària, ocupen els espais de visibilització consumista abans monopolitzats per les corporacions, com tanques publicitàries o anuncis, per difondre el seu missatge. Utilitzaran el distanciament i l'humor per, a través del collage i el muntatge, difondre el seu missatge de forma visual i impactant. En conseqüència, sorgiran nous significats que contradiuen el discurs del consum que domina les ciutats i construeixen una crítica a la ciutat des del centre mateix dels espais mediatitzats pel mercat.

Paraules clau: contra-publicitat, no-lloc, culture jamming, consum. 


\section{Radiografía de una ciudad para el consumo}

L a sociedad en redes en la que el individuo contemporáneo naufraga difiere mucho de la sociedad panóptica o la jaula de hierro que dibujaban los teóricos del pasado siglo. De una sociedad disciplinada y vigilada desde su mismo centro, hemos pasado a una sociedad licuada por los grandes flujos de información, una sociedad cuyo centro irradiador de sentido y autoridad se han vuelto rizomáticos y cuyo control se despliega en todos los ámbitos de la vida cotidiana.

Lyotard (2006) hablaba de la disolución de los grandes lenguajes que otorgaban sentido y univocidad a la voz que nos ordenaba desde arriba. Las grandes instituciones ponían límites y contenidos a un discurso social tejido por valores compartidos y un mismo caldo de cultivo cultural, social y religioso. Estos grandes discursos ceden la palabra a otros múltiples lenguajes: la antigua voz hegemónica de las instituciones cede ante el avance de la capacidad de opinión personal en las redes sociales, los antiguos receptores de información se convierten en productores y transmisores de la misma y la verdad revelada cede su lugar a la post-verdad.

La narrativa de nuestra sociedad conforma un texto disperso, dialógico y multifrénico. Un sujeto sin subjetividad, un yo desubstanciado, vaciado de un lenguaje propio y colapsado por la multiplicidad de discursos que se suceden. Un eterno presente de imágenes que no muestran nada más que la neurosis del individuo postmoderno atrapado en la maraña de estímulos que lo atraviesan: «Toda la cultura mass-mediática se ha convertido en una formidable maquinaria regida por la ley de la renovación acelerada, del éxito efímero» (Lipovetsky,1990, p. 232). Sin embargo, esta renovación no hace tambalear los cimientos de la cultura en la que se inscribe; bien al contrario, «pone de manifiesto de una manera pura la pasión tranquila por las pequeñas diferencias sin desorden ni riesgo: el éxtasis del cambio dentro de la continuidad. Emoción instantánea ligada a la novedad reconocible, no forma de subversión» (Lipovetsky,1990, pp. 232-233).

La ciudad post-fordista ha dado paso a una ciudad creada por y para el consumo. Una ciudad simulacro, recreada a su propia imagen y semejanza y cuya única esencia es dirigir el flujo de individuos por los canales de la 
producción y el consumo masivo. Fruto de la lógica del consumo, nuestras ciudades amanecen revestidas de anuncios y vallas publicitarias que se superponen y se sustituyen con premura. La novedad resulta el mayor aliciente para el consumo, y la continua reposición de estímulos que invaden nuestro espacio visual la forma más optimizada de fomentarlo.

La ciudad, marco de la nueva cultura de la eterna renovación e imperio de lo efímero como valor definitorio, debe adaptar su aspecto ante esta nueva era de consumo compulsivo, abandonando al individuo a la titánica tarea de elegir continuamente entre un innumerable inventario de elecciones posibles. La cultura mass-mediática:

[...] tiene el poder de hacer olvidar la realidad y entreabrir un campo ilimitado de proyecciones e identificaciones. Consumimos como espectáculo lo que vida real nos niega. [...] Estimulando las actitudes pasivas, embotando las facultades de iniciativa y creación y desalentando las actividades militantes, la cultura de masas no hace más que ampliar la esfera de la desposesión subjetiva y actuar como instrumento de integración en el sistema burocrático y capitalista. (Lipovetsky, 1990, p. 251)

El individualismo actúa desligando al individuo de sus congéneres. Liberado del peso de lo colectivo, «al sesgo de la mitología de la felicidad, del amor, del ocio, la cultura moda ha permitido generalizar los deseos de autoafirmación e independencia individual» (Lipovetsky, 1990, p. 253). La cultura del ocio ha generado una especie de opio del pueblo basado en oponer una compensación al absurdo cotidiano.

\subsection{Resignificar la ciudad del consumo. El shopping como matriz urbana}

De la sociedad disciplinaria a la sociedad del autocontrol, de la jaula de hierro al centro comercial como paradigma del urbanismo postmoderno: «la domesticación cruel y tiránica del hombre por el hombre, en vigor desde la noche de los tiempos, así como la instrucción disciplinaria, han sido reemplazadas por un tipo de socialización totalmente inédito, soft, plural, no coercitivo, y que funciona a través de la elección, la actualidad, el placer de las imágenes» (Lipovetsky, 1990, p. 257). La sociedad mass-mediatizada impulsa 
cierta desterritorialización del individuo, cierto desapego a los lugares a favor de las imágenes y las ideas.

El control social se optimiza mediante este desplazamiento que nos transforma de ciudadanos en consumidores: «el orden del mercado es mil veces más eficaz que el orden público: de donde la dinámica de la mercancía es más fuerte que el Estado» (Sarlo, 2010, p. 13). Igual que un centro comercial, una ciudad debe incitar al consumo; debe ser visual, atrayente, seductora; debe aparentar abundancia, sugerir un estilo de vida, mudar la piel de hormigón que la recubre con sus neones, vallas, carteles y estímulos en perpetua renovación. Ciudades sin memoria, sin personalidad propia, sin fisuras ni espacios atípicos. Ciudades sin identidad, como vallas publicitarias donde podemos superponer cualquier producto puesto a la venta.

Marc Augé define el no-lugar como lugares sin esencia ni personalidad, destinados a acelerar el tránsito de los individuos y el consumo. Espacios sin memoria y sin pasado. Puro presente. Los aeropuertos, los grandes hoteles, las autopistas, los supermercados, etc. no crean espacios singulares, sino que activan la circulación y el consumo. «Los espacios de paso, de tránsito, son aquéllos en los que se exhibe con mayor insistencia los signos del presente. Éstos se despliegan con la fuerza de la evidencia: los paneles publicitarios, el nombre de las firmas más conocidas inscrito con letras de fuego en la oscuridad de las autopistas [...], los ostensibles palacios del espectáculo, de los deportes, del consumo» (Augé, 2003, p. 104). Además, añade a esta lista los eriales, solares y espacios al margen del devenir urbano. A pesar de esta visión negadora de Augé que vacía la ciudad de significado, podemos abrir las puertas a conceptualizaciones más positivas que ponen en valor una reformulación de la experiencia espacial contemporánea. Manuel Delgado (2007) rescata la idea de no-lugar para redefinirla como un concepto superador y productivo desde el punto de vista social: la ciudad es una perpetua reformulación, un eterno cambio, un estado voluble y efímero que escapa de sí mismo. Una continua reconstrucción que es la posibilidad espacial de todo lo imaginable. La ciudad es, pues, un suceder, un devenir, una deriva, un perpetuo ciclo de reconstrucción y remodelación estética y estructural. La ciudad se escribe en gerundio: la ciudad mudable, reelaborada a cada paso. 
Incluso Augé señala la incertidumbre que causan los espacios vacíos por su potencialidad de ser: «En contra del presente, [este espacio vacío] subraya a un tiempo la presencia aún palpable de un pasado perdido y la inminencia incierta de lo que puede suceder: la posibilidad de un instante poco corriente, frágil, efímero, que escapa a la arrogancia del presente y a la evidencia de lo que ya está aquí» (Augé, 2003, p. 106). Admite, con estas palabras, la potencia de la ciudad como caldo de cultivo de algo nuevo, como emergencia de un sentido que está por llegar.

Delgado va más allá: «la no-ciudad — lo urbano — es la ciudad... sin la arquitectura» (Delgado, 2007, p. 82). El no-lugar no representa un espacio sino un suceder, un continuo ir acaeciendo, un «marco puramente acontecimiental» (Delgado, 2007, p. 50). El etnólogo observa en la ciudad un punto de indeterminación fascinante que abre posibilidades y experiencias inéditas, derivas azarosas y arbitrarias. Pone en valor «esa vida urbana entendida como práctica y organización de los trayectos-sucesos, del puro y mero acaecer, cuyo escenario es la calle, lejos y en buena medida de espaldas a la actividad institucional» (Delgado, 2007, p. 50). La ciudad fluye a la deriva, sin límites ni moldes:

[...] un agrupamiento polimorfo e inquieto de cuerpos humanos que sólo puede ser observado en el instante preciso en que se coagula, puesto que está destinado a disolverse de inmediato [...] una mera actividad, una acción interminable cuyos protagonistas son esos usuarios que reinterpretan la forma urbana a partir de las formas en que acceden a ella y la caminan. (Delgado, 2007, p. 12)

La sociedad del consumo, que creía haber detenido la historia, no ha sustraído al ciudadano la capacidad de intervenir en ese reajuste continuo que define la ciudad, para llenar de sentido los espacios vacíos. Se sobreentiende en el ciudadano un papel actante y protagonista a la hora de reconfigurar el entramado urbano y reapropiarse de la piel de la ciudad. En este rehacerse, el ciudadano puede encontrar su lugar de enunciación, abriéndose paso entre tal multifrenia discursiva y reconociéndose como punto de anclaje que, si bien no retiene el sentido espacial de la ciudad, ve reconocida su influencia en esta emergencia de lo nuevo que redefine lo urbano a cada paso.

En todo artefacto delicado, resistente y complejo, como la ciudad, hay también un potencial de desorden, encarnizado en desmentir el ideal de sistema 
integrado que contradicen la intemperie, los espacios abiertos, las calles, las vías de transporte y, sobre todo, la competencia por ocupar materialmente los edificios y la tierra. (Sarlo, 2010, p. 13)

En ello vemos diferentes formas de resistencia frente al orden neoliberal. Los individuos participan activamente en el proceso de construcción y reformulación continua de identidades, relaciones sociales, prácticas y sensibilidades. Lefebvre ya afirmaba que «el derecho a la ciudad no puede concebirse como un simple derecho de visita o retorno hacia las ciudades tradicionales. Sólo puede formularse como derecho a la vida urbana, transformada, renovada» (Lefebvre, 1969, p. 138). Hablar del derecho a la ciudad significa, entonces, reclamar el poder catártico inherente al ciudadano para reformular sus bases.

Los espacios del espectáculo y del consumo serán, desde ahora, los lugares desde los que repensar una práctica política y una reconstrucción social. El individuo deberá hallar su lugar de enunciación y reconocimiento en estos espacios, aunque éstos sean el resultado de un plan urbanístico que ha prescindido de él como sujeto. Si la sociedad configura ciudades para el tránsito y el consumo, será en este discurso en el que debe inscribir su voz, de forma directa, transversal o subversiva. Retomar la historia desde los espacios despojados de memoria, abrir grietas en los palacios del consumo y desde allí proyectar otros modos de ser ciudadanos. Asignar nuevos significados a la ciudad vaciada por la lógica del capital. En definitiva, eso que García Canclini llama «reconceptualizar el consumo» (García Canclini, 1995), redefinir al consumidor, asignar nuevos roles a los actantes y deconstruir la ciudad del consumo para hacer que hable con nuevas voces.

Delgado habla de reservas naturales para referirse al carácter tranquilizador y excepcional de estos espacios del consumo vigilados por cámaras y al refugio de cualquier disrupción. $Y$ en este punto vemos cómo la ciudad adopta este modelo como matriz sobre la que se construye lo urbano: «lo que llama la atención de este tipo de ámbitos es la manera como han impreso su estilo a las concepciones actuales del espacio público en general. [...] De hecho, cada vez más puede afirmarse que no es que el centro comercial imite la ciudad, sino que es la ciudad la que copia el modelo que le prestan los centros comerciales» (Delgado, 1998, p. 37). 
Hilando los argumentos, llegamos a la conclusión de que el centro comercial se proyecta como un nuevo paradigma definitorio de la ciudad, alejándose cada vez más del panóptico, de la jaula de hierro o del campo de concentración como modelos sobre los que pivota el entramado social. Beatriz Sarlo parece ratificar esta idea cuando afirma que el centro comercial es la nueva plaza pública: «El shopping no es simplemente una parte de la ciudad sino su reemplazo por un sistema nuevo, donde se atenúa o desaparece lo que caracterizó, en el pasado, lo urbano» (Sarlo, 2010, p. 19).

Y en esta ciudad nadan las múltiples subjetividades que constituyen una multitud en busca de su propia voz, de su propia historia, de sus vínculos comunitarios. Si el centro comercial contextualiza al consumidor postmoderno, debe ser éste el espacio donde se recomponga su rol como ciudadano y actante en la reformulación de la ciudad. Delgado, lejos de considerar el consumo un instrumento al servicio de la opresión monetarista, como hizo la Escuela de Frankfurt, lo observa como un catalizador de nuevas atribuciones y significados. Los consumidores «no son zombis sin voluntad... sino ciudadanos que piensan, que saben lo que quieren» (Delgado, 1998, p. 43). El etnólogo afirma que:

[...] el consumo es un elemento estratégico en el proceso de reproducción social y no replica mecánicamente los rasgos de la estructura social, de manera que el consumidor estaría, desde este punto de vista, en condiciones de imponerle sus propios significados a los productos que consume. [...] Desde esta óptica los consumidores que pululan por los centros comerciales no son víctimas inocentes de un espejismo malévolamente colocado ante ellos por un poder económico y político pérfido, sino que han de ser considerados como agentes activos que interpelan su realidad social a partir de los usos que hacen tanto de los objetos que se exponen como del mismo territorio donde se exponen. (Delgado, 1998, p. 41)

Es cierto que el ciudadano se ha convertido en cliente, pero también el cliente se ha ciudadanizado; ha adquirido la potestad de dirigir su propia deriva en el imperio del consumo, sus derechos, su dignidad como miembro del reparto. El centro comercial es el nuevo espacio público, el nuevo espacio de confluencia. Una nueva plataforma para conformar nuevas formas de sociabilidad. Una vez disueltos los grandes discursos hegemónicos, «es el mundo de la publicidad y del consumo el que nutre una especie de folklore 
popular de alcance universal y, por tanto, un campo abierto a la comunicación intercultural» (Delgado, 1998, p. 42). El lenguaje de los mass-media es el código que va a elaborar el lenguaje de su propia subversión. Algunos teóricos han defendido la potencialidad de una nueva forma de comunidad establecida sobre las bases del espacio y el discurso del consumo. Como indica Delgado, «los llamados consumidores producen una cultura no signada, no legible, no simbolizada, inestable, pero muy poderosa» (Delgado 1998, p. 44). Y Lefebvre señalaba con acierto que:

En estos lugares privilegiados, el consumidor acude también a consumir el espacio; la reunión de objetos en las tiendas, escaparates, estantes, se convierte en razón y pretexto de la reunión de personas que ven, miran, hablan, se hablan. Y, a partir de la confluencia de cosas, pasa a ser terreno de encuentro. Lo que se dice y se escribe, es, ante todo, el mundo de la mercancía, el lenguaje de las mercancías, la gloria y ascensión del valor de cambio. Esta centralidad tiende a reabsorber el valor de uso en el cambio y el valor de cambio. Sin embargo, el uso y el valor de uso resisten pertinazmente: irreductiblemente. (Lefebvre, 1969, p. 154)

Beatriz Sarlo se refiere a las declaraciones de Jon Jerde al New York Times: «la adicción al consumo es lo que reunirá a la gente» (Sarlo, 2010, p. 16). Paradójicamente, la ciudad del consumo y su individualizadora es la que dará voz al ciudadano y se convertirá en un nuevo campo político y social. Mientras los sindicatos pierden afiliados, las asociaciones que defienden al consumidor ganan adeptos. «Jon Jerde descubre que el shopping mall produce comunidad allí mismo donde parecía haberse perdido para siempre» (Sarlo, 2010, p. 16) Se abren así nuevos espacios a la significación, nuevas posibilidades para la actuación y nuevas perspectivas para la ocupación del espacio público. Se activa así el papel del consumidor a través de los usos que se hacen de los nuevos espacios destinados al consumo de masas.

\section{Reescribiendo la piel de la ciudad: el derecho a la subversión}

Hallamos, en el campo de la lucha social, diferentes iniciativas que defienden el derecho a la vivienda, al espacio privado, a la intimidad y al desenvolvimiento personal. El derecho al hábitat, el derecho a lo doméstico. 
Pero también es cierto que paralelamente vislumbramos una pulsión por recuperar el derecho a la calle, a la intemperie que nos une como miembros de la comunidad, al espacio social, al ágora de la polis. Recuperar las calles para los ciudadanos, para su uso lúdico, político y cultural. Esta apropiación, física o simbólica, del espacio urbano conlleva una preocupación por reparar el tejido social, por darle otra forma más acorde con los tiempos y con el nuevo espacio que habita el ciudadano. Como señala Lefebvre:

El derecho a la ciudad se manifiesta como forma superior de los derechos: el derecho a la libertad, a la individualización en la socialización, al hábitat y al habitar. El derecho a la obra (a la actividad participante) y el derecho a la apropiación (muy diferente del derecho a la propiedad) están imbricados en el derecho a la ciudad. (Lefebvre, 1969, p. 159)

El elemento artístico, como vamos a ver, juega un papel muy importante en esta partida por el espacio. En la mayoría de prácticas que optan por recuperar el discurso urbano se entrevé un gesto artístico como modo de reapropiación del sentido de las calles y sus múltiples formas de decir y enunciar lo urbano. Lefebvre vio necesaria, a tal efecto, «una teoría integral de la ciudad y la sociedad urbana que utilice los recursos de la ciencia y del arte» (Lefebvre, 1969, p. 139). Y el arte no sólo cumple una función estética o meramente embellecedora: el arte representa un papel subversivo, catártico, emancipador, creador de nuevos modelos de relación con lo urbano. El arte como modo de intervención social:

Poner el arte al servicio de lo urbano no significa ornamentar el espacio urbano con objetos de arte. Esta parodia de lo posible se denuncia a sí misma como caricaturesca. Esto quiere decir que los tiempos-espacios se convierten en obra de arte y que el arte pasado se reconsidera como fuente y modelo de apropiación del espacio y del tiempo. [...] El arte, prescindiendo ya de la representación, el ornato, la decoración, puede convertirse en praxis y póiesis a escala social: el arte de vivir en la ciudad como obra de arte. (Lefebvre, 1969, pp. 158159)

La ciudad es una reconstrucción eterna, un producto, una obra en la que el ciudadano debe verse representado como creador y parte de la obra. 
Tal vez uno de los primeros intentos por establecer una nueva relación entre el ciudadano y la ciudad lo ofrecen los miembros de la Internacional Situacionista. Éstos, liderados por Guy Debord, vieron en la deriva psicogeográfica urbana sin rumbo ni destino prefijados, guiada por el azar y los estímulos espontáneos, una práctica contracultural que convierte un paseo por la ciudad en una experiencia artística en sí misma. Se señala un disfrute artístico en el mero hecho de ser ciudadanos; individuos rescatados de las garras de lo cotidiano por la misma ciudad que les había asignado un papel de meros transeúntes.

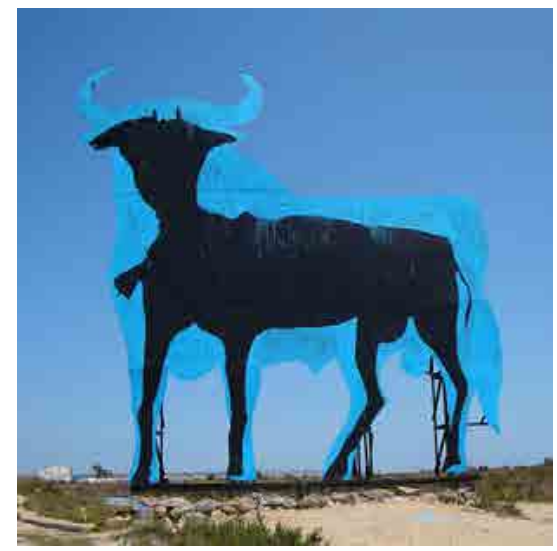

Figura 1.

Posteriormente, el grafiti como práctica ilegal establecería las bases de la subversión artística. La ciudad se convierte en un papel en blanco al que darle sentido en tanto lo que es: un vacío y, por ende, la posibilidad de cualquier representación o experiencia. Las paredes se convierten en el canal por el que se destila la voz de los que no encuentran forma de expresar su propia existencia, su latir como miembros de la comunidad. Una forma paradójica de representación, ya que apuestan por una visibilidad extrema desde el anonimato. 


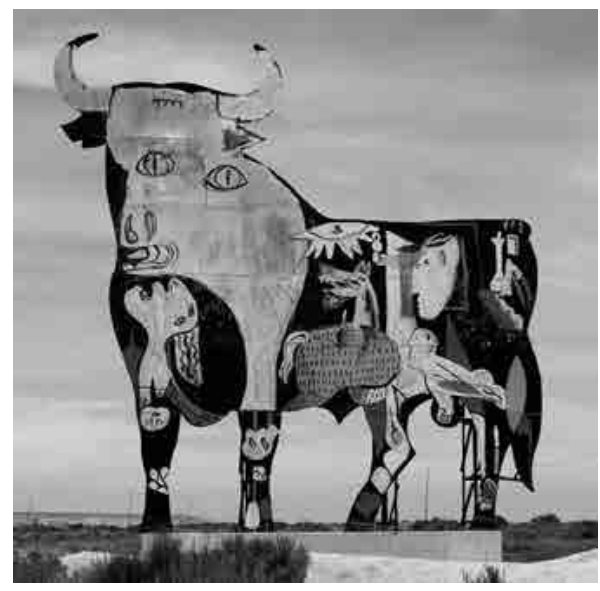

Figura 2.

Más tarde surge el Street Art, una forma más digerible de intervención urbana que ya puede llamarse artística (en tanto que los grafiteros no se consideran artistas sino vándalos). Esta desviación del grafiti, más soft y menos ilegal, se construye sobre las mismas directrices que éste. Sin embargo, el objetivo va dejando de ser la mera visibilidad y se acoge un criterio estético que juega con la mezcla de códigos, el juego simbólico, el humor, el arte, etc. Embellecer la ciudad, convertirla en una experiencia artística llevando al extremo la museificación de las calles.

En muchas ocasiones es imposible deslindar el Street Art del activismo. Valga como ejemplo el toro de Osborne rediseñado por el artista Sam3 en Santa Pola (fig. 1). Vemos cómo una vaquilla se recorta contra cielo, estableciendo un paralelismo con la crisis del país. En otra ocasión ha pintado parte del Guernica de Picasso en la superficie del toro como ataque a la tauromaquia (fig. 2). Una vuelta de tuerca la suponen otras muchas formas de intervención social que, con una perspectiva política basada en el activismo, reclaman la calle como espacio propio. Uno de los más famosos es el movimiento Reclaim the streets, cuyas acciones van dirigidas a convertir los lugares de paso en lugares de confluencia y acción social. RTs corta repentinamente las principales arterias de las ciudades con camiones pertrechados con altavoces transformando las ciudades del tránsito en una experiencia festiva y musical para el viandante. 
Objeto de otro estudio más amplio y detallado merecen ser las acampadas del 15-M que ocuparon las principales plazas de nuestras ciudades. Baste aquí señalar que, más allá del acto físico de la ocupación de un espacio público, subyace el acto simbólico de apropiarse del escenario donde sucede lo social, de crear un ágora para pensar nuevas formas de socialización y lucha por el reconocimiento como ciudadanos. Ocupar el centro mismo de las ciudades, re-bautizar plazas y paradas de metro, resignificar la calle como espacio de encuentro y enunciación. Del mismo modo operan los resortes de Occupy Wall Street, en EEUU.

Podemos citar innumerables ejemplos de prácticas que, en definitiva, pugnan por recuperar el espacio público fagocitado por el hambre voraz del neoliberalismo: colectivos que escriben versos en paredes y pasos de cebra en un intento de poetizar el entorno; el yarn bombing o guerrilla del ganchillo que recubre el mobiliario urbano con tejidos elaborados con ganchillo para embellecer la ciudad; performances como la que llevó a cabo el movimiento «Mujeres Creando», en Bolivia, cubriendo el Obelisco con un enorme preservativo parar criticar el orden patriarcal ante el que responde toda construcción nacional. En todos los casos, el protagonista de esta subversión es «el peatón, el transeúnte, que de pronto decide usar radicalmente la calle, actuarla, decirla diciéndose y que, haciéndolo, se apropia de ella. Aunque acaso fuera mejor decir que, sencillamente, la recupera» (Delgado, 2007, p. 181). En Manual de guerrilla de la comunicación se citan acciones que tienen como objetivo, a través de la apropiación de los monumentos bélicos que hacen apología de la guerra, transmitir un mensaje pacifista. Así se sacan las máscaras, se evidencia la inmoralidad y crueldad de todo conflicto armado. Estos activistas sustituyen las placas conmemorativas por lemas como «un soldado es un asesino», o pintan de colores fluorescentes bustos y estatuas ecuestres. Otra técnica es la de llenar de alquitrán y cubrir con plumas las estatuas de los soldados, como hicieron las activistas de Blood, Sweat and Teer (Sangre, Sudor y Alquitrán) en 1985 en la ciudad de Marbach (Blisset, 2000, p. 103). El discurso hegemónico del monopolio de la violencia que justifica la guerra como medio de reafirmación nacional se ve tergiversado por esta práctica artística de guerrilla que se vale de la ciudad como escenario de sus acciones activistas. 


\section{Deconstruir la ciudad del consumo. Activismo y contrapublicidad}

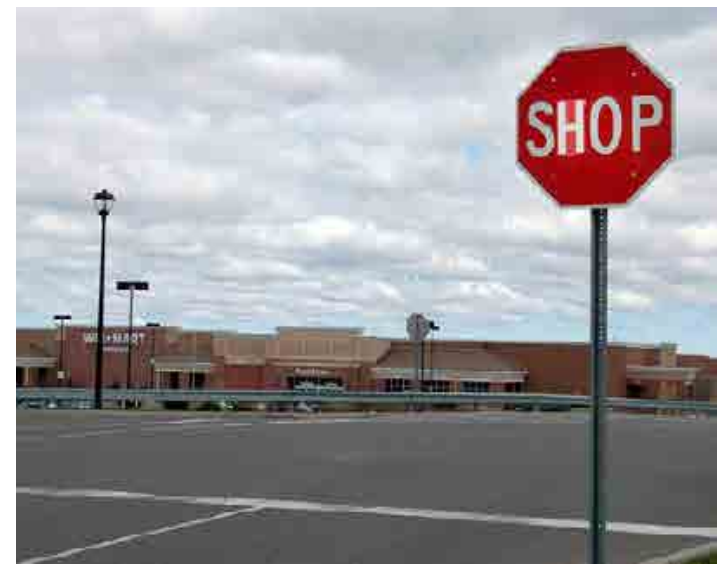

Figura 3.

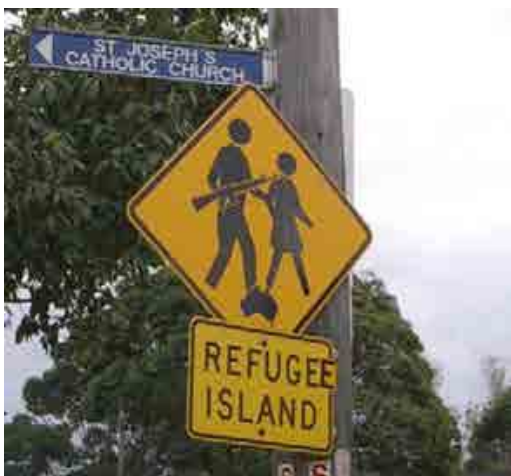

Figura 4.

En este trabajo vamos a centrarnos en algunas prácticas puntuales que, de forma específica, se dedican a desenmascarar el consumismo con sus mismas armas, haciendo emerger nuevas formas de relación del actante con un entorno urbano construido según la matriz del centro comercial.

El llamado Culture Jamming o contrapublicidad se perfila como una táctica que trata de alterar los anuncios publicitarios. Atacan el contenido del mensaje comercial y vuelven el marketing contra las propias corporaciones. $\mathrm{Su}$ objeto de acción son vallas publicitarias, carteles, mobiliario urbano, señales de tráfico... (fig. 3 y 4). Cualquier imposición visual impuesta por el imperio del consumo. Centran sus esfuerzos en desmontar la gran maquinaria del consumismo, hacerla estallar para que revele nuevos sentidos a través de la ácida ironía, el humor y la sátira. Naomi Klein admite que es difícil rastrear los orígenes de esta práctica que hunde sus raíces en el détournement de los situacionistas franceses. Este método compositivo consiste en reciclar una imagen (normalmente viñetas de cómic) para, añadiéndole otros elementos (normalmente textos políticos), conformar sugerentes diálogos entre los personajes. Una idea, por otra parte, que deriva del Dadaísmo y otras vanguardias. 


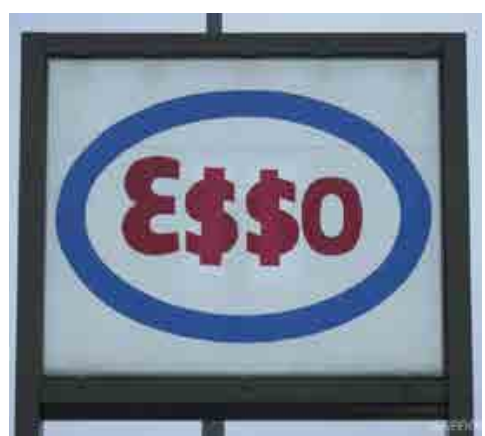

Figura 5.

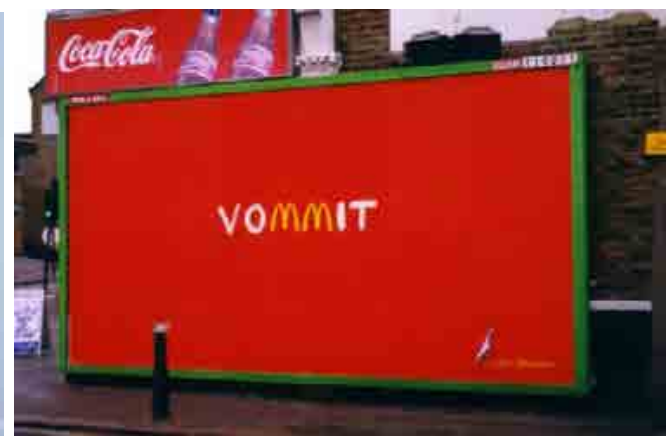

Figura 6.

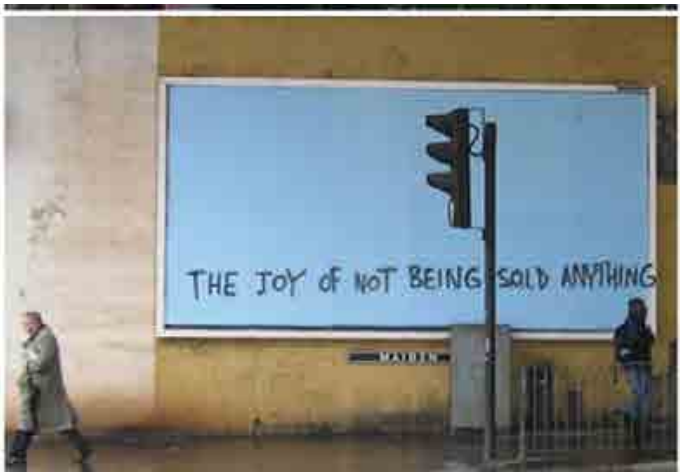

Figura 7.

Los culture jammers, o piratas publicitarios, utilizan el collage para alterar los anuncios publicitarios con una finalidad bien concreta: desmontar el andamiaje que sustenta la engañosa fachada que recubre las entrañas del consumismo. Subvierten los códigos para que el mensaje diga justo lo contrario de lo que quería decir. El ímpetu mercantilista se vuelve en contra de las corporaciones con sólo añadir unas letras o sustituir parte de la imagen. El logro es valerse de los mismos códigos que conforman el discurso publicitario, hablar con el mismo lenguaje, utilizar el mismo horizonte de expectativas de la empresa para vomitar un mensaje revelador y contestatario (fig. 5 y 6). Para ello los activistas se valen del distanciamiento, una torsión del lenguaje:

[...] escoger formas, acontecimientos, imágenes e ideas existentes y cambiar su transcurso normal o su representación usual. [...] En cuanto surjan unos elementos inesperados o imprevistos en el proceso de comunicación, la normalidad con la cual las percepciones se adaptan a las estructuras de la gramática cultural 
se ve perturbada. [...] Así se posibilita una visión crítica frente a los modelos usuales de la percepción. (Blisset, 2000, p. 46) (fig. 7)

El poder de la mercadotecnia para crear valores es utilizado por los piratas publicitarios para desenmascarar la sociedad de consumo y dejar entrever el vacío que late bajo la máscara. En palabras de Klein, los rompeanuncios «no invierten los mensajes, sino que más bien los mejoran, los editan, los magnifican o los desenmascaran. [...] la piratería publicitaria correcta es una visión de rayos $\mathrm{x}$ del subconsciente de la campaña publicitaria que no revela un pensamiento opuesto a ella, sino la verdad profunda que se esconde tras las capas de eufemismos publicitarios» (Klein, 2001, p. 332).

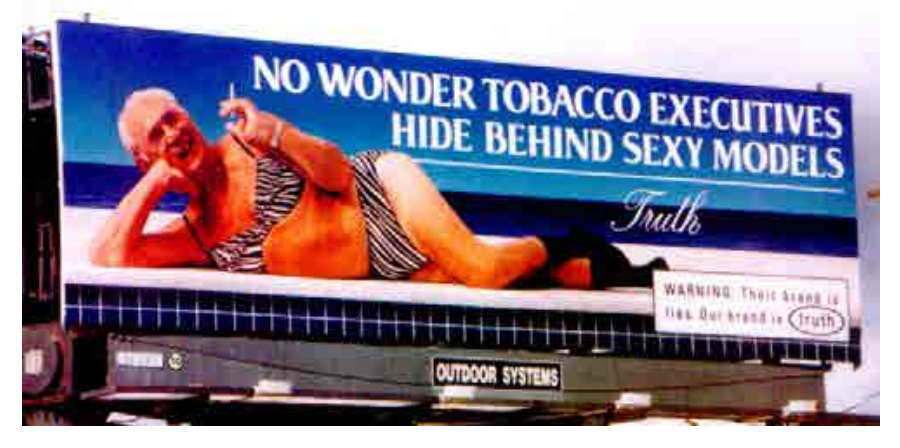

Figura 8.

Humor y activismo son las dos caras de la misma moneda: es la ironía la que hace que el mensaje se retuerza sobre sí mismo, engrasando los goznes de este mecanismo distanciador (fig. 8). En esto, el humor revela cierto poder subversivo y transformador. La ironía produce nuevos sentidos alterando los códigos que fluyen alegremente por los mass-media y redescubriendo un potencial contracultural en este lenguaje cacofónico y redundante. Como también hizo el Pop Art, la piratería publicitaria toma referentes culturales propios de la sociedad de consumo y los descontextualiza, creando un campo abierto a la tergiversación significativa. Y la postmodernidad es un caldo de cultivo excelente para los discursos basados en el humor como método constructivo del mensaje: «la ausencia de fe postmoderna, el neonihilismo que se va configurando, no es ni atea ni mortífera, se ha vuelto humorística; [...] como las otras grandes divisiones, la de lo cómico y lo ceremonial se difuminan» (Lipovetsky, 2003, p. 137) (fig. 9). 


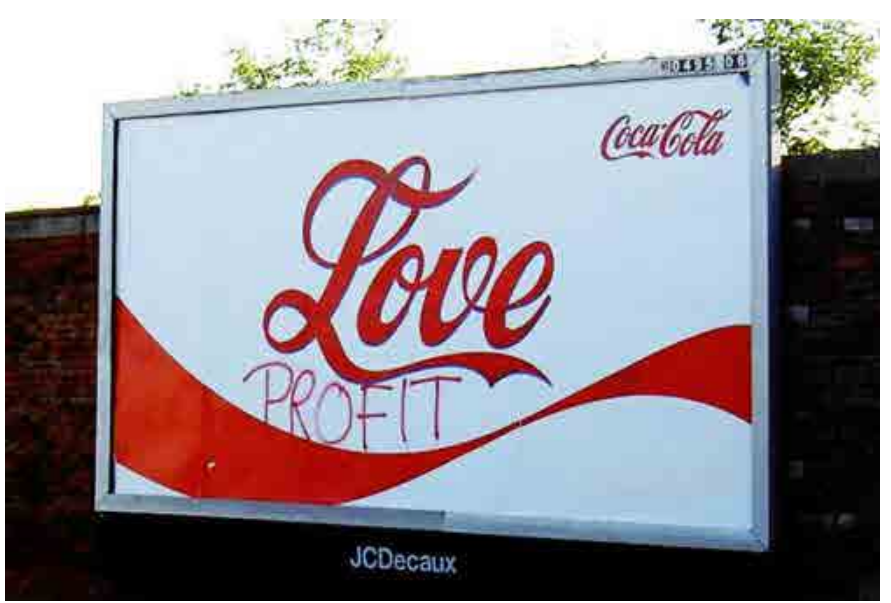

Figura 9.

Blisset, desde el activismo, señala el carácter perturbador de estas acciones.

Los snipers son francotiradores semióticos. [...] Su especialidad es la introducción insidiosa y desapercibida de signos y símbolos en el espacio público. Su objetivo es el cambio, comentario, corrección o aclaración de los mensajes [...] de carteles, monumentos, señales o similares, o bien el intento de usar paredes o fachadas aparentemente neutrales para fines ajenos mediante los grafiti. La mayoría de los ataques de los snipers representan a la vez violaciones prohibidas de la propiedad privada. [...] La snipera trabaja con diferentes intervenciones gráficas y lingüísticas, a menudo fragmentarias. Se vale del material que encuentra durante sus imprevisibles incursiones en el terreno del enemigo, en sus espacios y sus objetos. Lo completa o lo desfigura con sus proyectiles semióticos, con fragmentos, símbolos o imágenes. Cambia el sentido (distanciamiento) del mensaje original y en determinadas ocasiones lo invierte. Mark Dery habla en este contexto de terrorismo artístico. (Blisset, 2000, p. 94)

Gregory L. Ulmer retoma la definición de collage propuesta por el Grupo $\mathrm{Mu}$ de Lieja para dar ejemplo de lo que llama el potencial productivo del collage: «tomar un cierto número de elementos de obras, objetos, mensajes preexistentes e integrarlos en una nueva creación a fin de producir una totalidad original que manifiesta rupturas de diversas clases» (Ulmer, 1998, p. 127). El nuevo mensaje no sólo será original, sino que irá revestido de cierto carácter demiurgo y potencialidad constructiva de nuevos significados. 


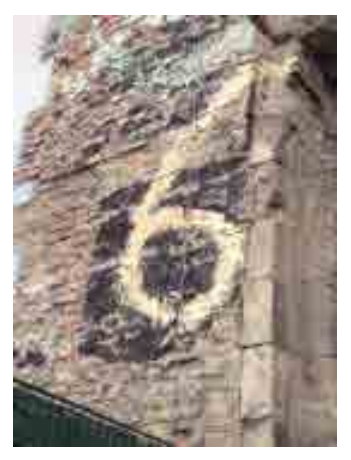

Figura 10.

Blisset, por su parte, traza una frontera entre el collage, que se vale azarosamente de elementos arbitrarios, y el montaje, cuyas técnicas «están determinadas por el objetivo que se quiere conseguir y por formas de agitación política conscientemente escogidas» (Blisset, 2000, p. 86). Es esa relación con el activismo político, su razón de ser como forma de reflexión social y política, lo que hace del montaje una práctica esencialmente subversiva.

Asistimos a una apropiación de una estructura discursiva establecida, naturalizada y hegemónica usada en detrimento de su productor original. $\mathrm{La}$ narrativa del consumo:

[...] es un sistema de ordenación, cuyo poder se basa en ser aceptado de forma incuestionable. Se trata, pues, de alterar el orden pacífico de los signos para poder llamar la atención sobre este sistema de orden y sus funciones estabilizadoras. Eso significa, en el mejor de los casos, adueñarse de sus espacios vacíos, decir lo no dicho y desvelar al mismo tiempo cómo actúan de manera oculta los vacíos y los silencios en el lenguaje. Tal tergiversación y cambio de sentido agrede los fundamentos simbólicos del orden social. (Blisset, 2000, pp. 89-90)

Son muchos los colectivos y activistas anónimos que dedican sus esfuerzos a desenmascarar a las corporaciones a través del culture jamming a través de formas muy diversas. Citaremos a Mr. Six, quien misteriosamente pinta esta cifra en aquellos lugares de Berlín que merecen ser reformulados: solares, viviendas semiderruidas, carteles, vallas, anuncios perniciosos... Más allá de la discusión por buscar significados semióticos al seis como símbolo inacabado, contorsionado, etc., habrá que señalar su valor como motor de rediseño y potencialidad comunicadora. Una simple cifra apunta a la ciudad 
que se reconstruye diariamente, al grado cero de la ciudad como potencia y posibilidad de cambio (fig. 10).

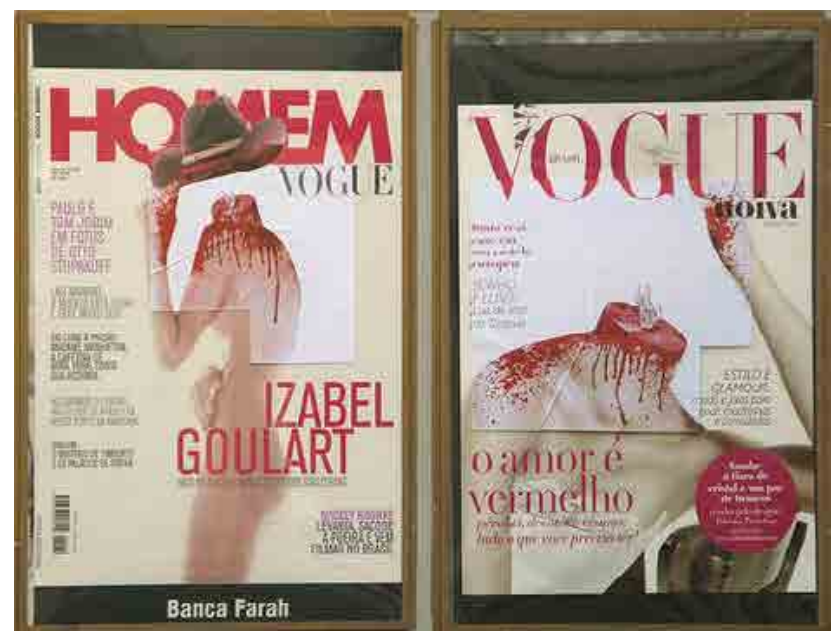

Figura 11.

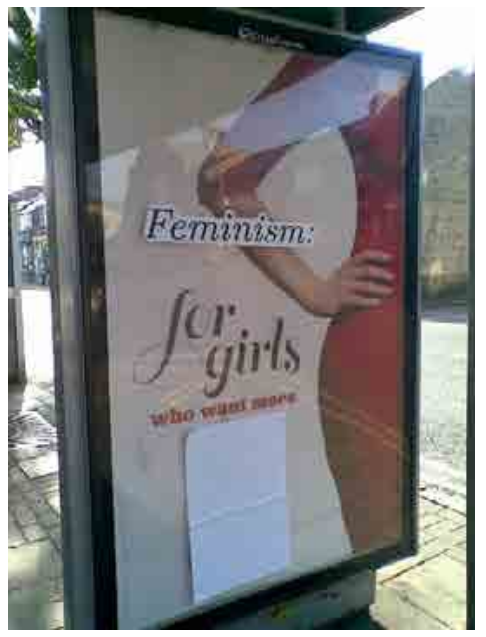

Figura 12.

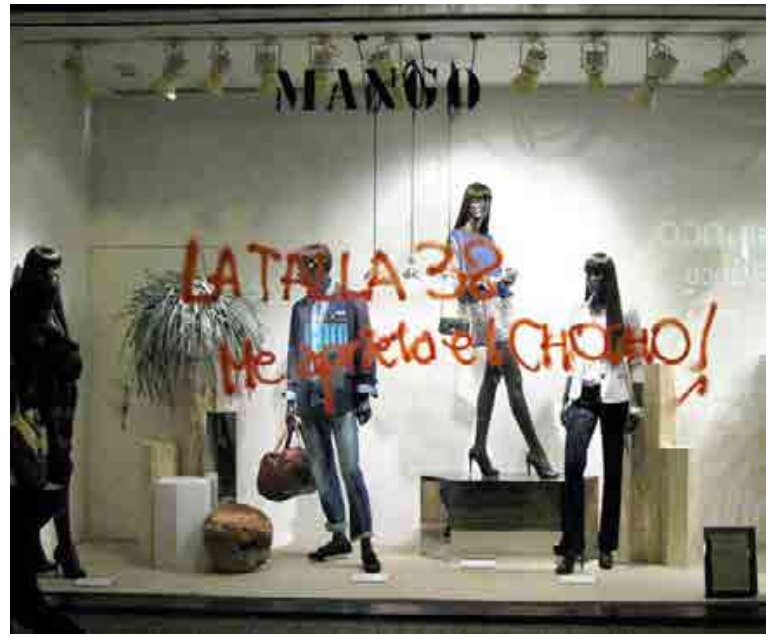

Figura 13.

Desde una perspectiva de género, hay que subrayar la enorme actividad de los movimientos feministas en estas prácticas subversivas que optan por la distorsión del lenguaje del consumo para revelar la miseria que esconde tras su fachada de cuerpos turgentes y pieles sin celulitis (fig. 11, 12 y 13). Klein (2011) se refiere a las calaveradas. Pegando adhesivos con calaveras sobre la cara de las modelos que muestran los anuncios publicitarios, estas activistas revelan el verdadero significado de los anuncios y subrayan la ausencia valores que sostiene la maquinaria del consumo, llevando al extremo la del- 
gadez como ideal de belleza femenino. Si la feminidad ha sido un elemento moldeado por la industria del marketing, han sido también los movimientos feministas los que han atacado con mayor crudeza la inanición ética de las empresas. Estas iniciativas individuales y anónimas, que se despliegan y desaparecen a modo de guerrilla urbana, representan pequeñas acciones locales que entroncan con una perspectiva global de apropiación del espacio urbano para desenmascarar la idea de la mujer como construcción comercial cosificada. Pintar de blanco los ojos de las modelos que adornan los anuncios dándoles una imagen de zombis, así como acné o restos de sangre y vómito en la comisura de sus labios es otra práctica activista que abunda en la misma idea.

En otro sentido, pero valiéndose del mismo método, actúa el Hitlerizing, práctica sencilla que consiste en pintar bigotitos de Hitler en la cara de políticos que ilustran las vallas en la campañas electorales. Sus grandes sonrisas se vuelven maliciosas bajo este símbolo de maldad.

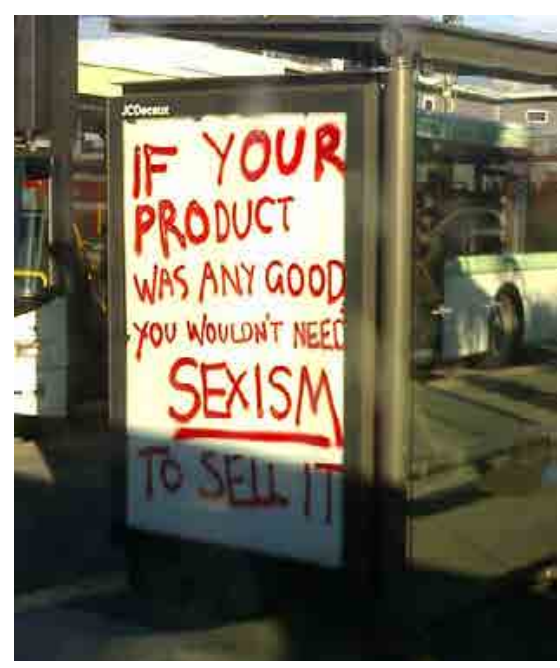

Figura 14.

Dentro del billboard banditery debemos referirnos a Adbusters, una publicación trimestral que propone ejemplos de intervención contrapublicitaria en EeuU y Canadá. También existen movimientos activistas organizados que llevan a la práctica estas acciones. El Billboard Liberation Front funciona desde 1977 en San Francisco reivindicando el uso ciudadano de las vallas publicitarias. En esencia, no se oponen a su existencia y sí al monopolio de las corporaciones sobre este espacio de visibilidad (fig. 14). «En el fondo no 
son adversarios de los carteles y los paneles de publicidad (billboards). Bien al contrario: defienden que la propaganda no debería ser un medio exclusivo para grandes empresas, sino que todos los individuos tendrían que tener acceso a las superficies de publicidad. [...] Su estética de trabajo exige más bien una mejora de los paneles publicitarios», lo que ellos mismos llaman «el arte y la ciencia de la mejora de paneles publicitarios» (Blisset 2000, p. 95). También los activistas de Buga Up comparten este objetivo, mejorando los anuncios de ciertas marcas comerciales con sus aerosoles (fig. 15).

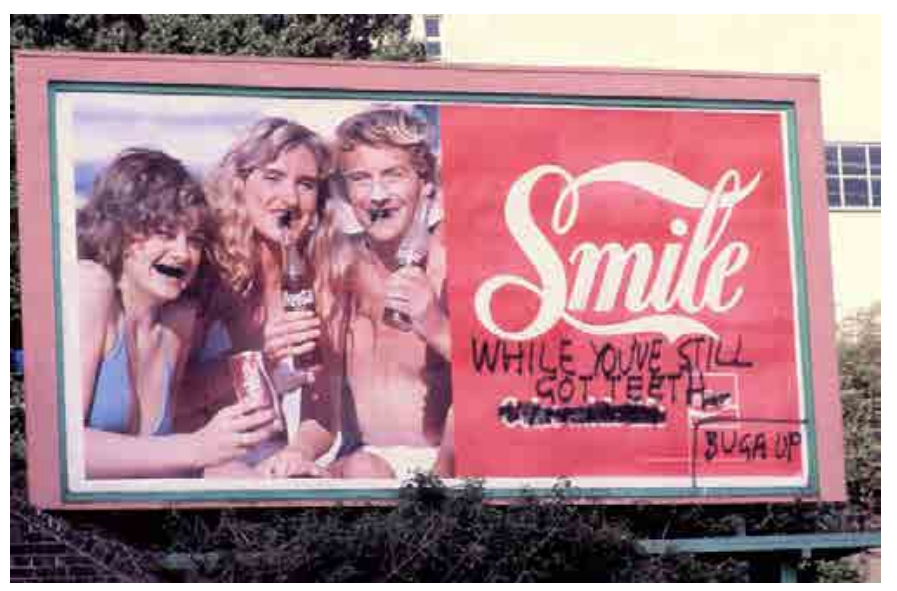

Figura 15.

Los activistas barceloneses de AENA (Al Enemigo Ni Agua) se valen de las máquinas automáticas de cobro en las zonas de aparcamiento y cajeros de banco para atacar a la lógica del consumo adhiriendo pegatinas en las que se lee "Averiado, Disculpen las molestias". Esta técnica del boicot supone una acción directa contra los flujos de capital, dificultando la recaudación e implicando a los consumidores en el juego.

Existe incluso un día dedicado a la ausencia de actividad comercial, en el que se incita al ciudadano a no consumir a lo largo de toda la jornada. El viernes posterior al día de Acción de Gracias, se celebra en todo el mundo el llamado Día Mundial Contra el Consumismo. Esta jornada es aprovechada por numerosos grupos para hacer visible una crítica a la lógica del capital (fig. 16) . 


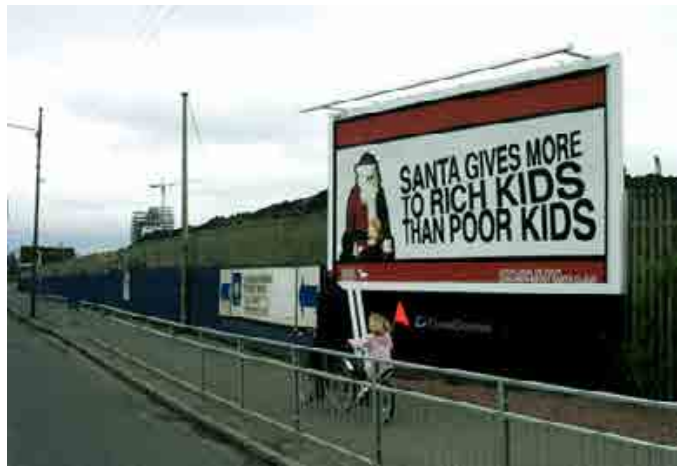

Figura 16.

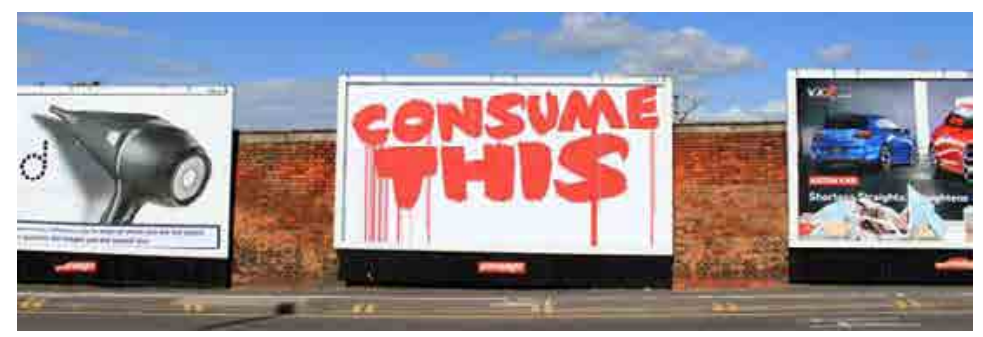

Figura 17.

El grupo subversivo King Mob de Inglaterra llegó a colgar carteles suplantando la estética de los supermercados en sus alrededores anunciando el que llamaron free shopping day, de tal forma que hubo que convencer a los clientes de que debían pagar lo que trataban de llevarse sin más. Los mismos activistas se disfrazaron de Papá Noel el día anterior a la Navidad regalando a niños y clientes juguetes y mercancías de las estanterías de los comercios de Oxford Street en Londres que los propios comerciantes tuvieron que quitar de las manos de los niños que se resistían a soltarlos (fig. 17).

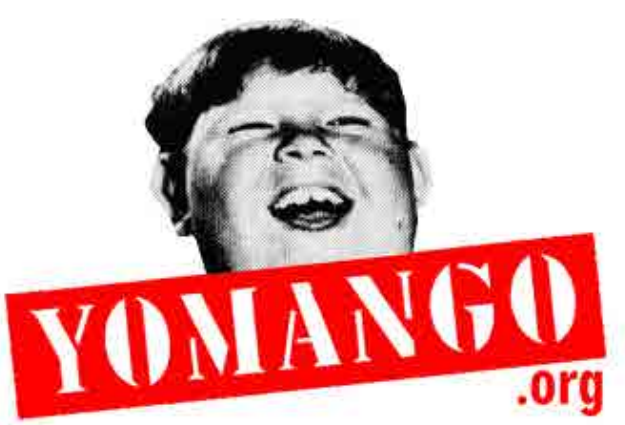

La felicidad no se puede comprar

Figura 18. 
En nuestro país, destaca YoMango, quienes, lejos de definirse como colectivo o movimiento social, se han constituido en forma de corporación mercantil, adoptando hasta el extremo el discurso y roles empresariales. Formalmente, actúan como una parodia, un simulacro empresarial que suplanta al ámbito corporativo valiéndose de sus propios códigos. Una empresa con muchas franquicias alrededor del mundo, reunidas bajo el mismo logo y coordinadas por su Departamento de Marketing (fig. 18).

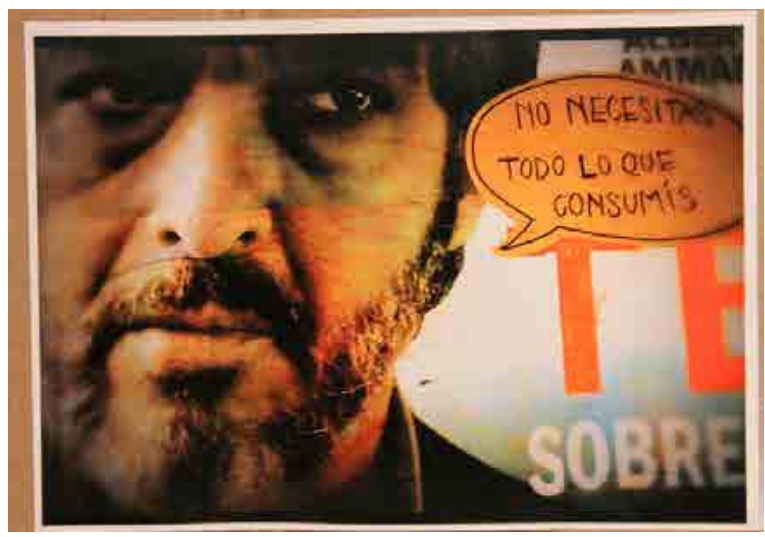

Figura 19.

Sus acciones, entre otras, se centran en una especie de saqueo lúdico de diversos centros comerciales con peculiares estrategias: robar bailando tango, disfrazados, con música, haciendo saltar las alarmas... Los activistas salen del centro comercial con carros llenos de productos ante la mirada impasible de cajeros y agentes de seguridad. El valor significativo de este hurto colectivo y ritual hace coincidir la agitación política y la restitución de lo cotidiano como campo de batalla político. Como leemos en Manual de Guerrilla de la comunicación, «la manera más simple de atacar la sociedad de consumo consiste en comprar gratis. A la gente le gusta tanto robar que así se junta la práctica política con necesidades cotidianas muy concretas» (Blisset, 2000, p. 108).

Se trata, en esencia, de una performance que va más allá de la propia usurpación y que apunta a recalificar la esencia del individuo-consumidor, a replantear el estatuto del ciudadano reducido a su rol clientelar, a repensar el lugar del activismo contestatario en el centro mismo irradiador de contenidos y valores: el centro comercial. Si Salvador Allende anunciaba cómo se 
abrirían las grandes alamedas por donde pase el hombre libre, hoy se anuncia que se abrirán las puertas de los centros comerciales por donde salga el ciudadano convertido en un nuevo consumidor. Se traslada el campo social: de la plaza a los centros de consumo. Se transforma el lenguaje contestatario: del fanzine a la parodia del consumo.

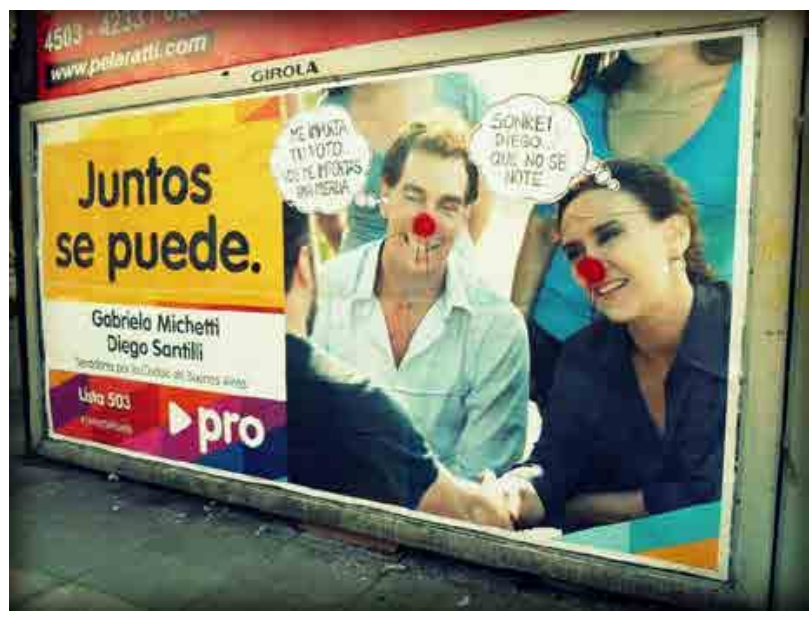

Figura 20.

Debemos también incluir en este artículo a los argentinos Proyecto Squatters, quienes se valen en numerosas ocasiones del bocadillo de los cómics para poner en boca de los políticos las palabras que dirían en un mundo donde la política no fuera un simulacro. Del mismo modo, ponen en boca de actores y futbolistas famosos frases en donde se explicita un mensaje subversivo (fig. 19 y 20). Si la mercadotecnia utiliza personajes famosos para vender sus productos, la contrapublicidad va a usar este mismo recurso para volver el mensaje contra ella.

Otro colectivo que merece nuestra atención es Overpass Light Brigade. Se trata de un proyecto colaborativo norteamericano que, con grandes letras luminosas, hacen visibles sus mensajes por las noches en autopistas, plazas y diversos lugares públicos. Esta iniciativa se plantea como una contrapartida a los innumerables mensajes publicitarios y/o institucionales que saturan el campo visual de nuestras ciudades. En esencia son una respuesta contra-hegemónica que se abre paso entre los múltiples mensajes que contaminan el paisaje urbano, buscan su lugar y su visibilidad. 


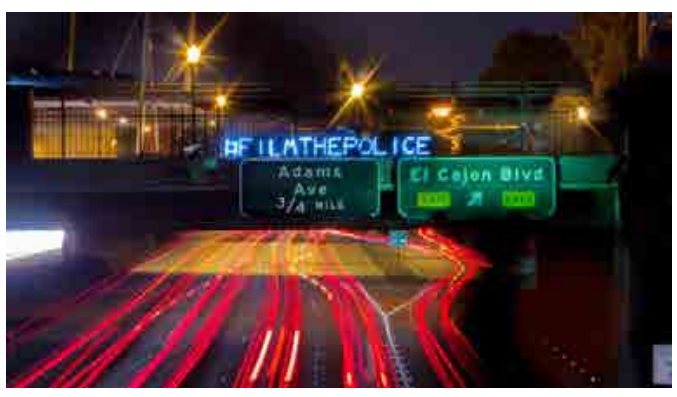

Figura 21.

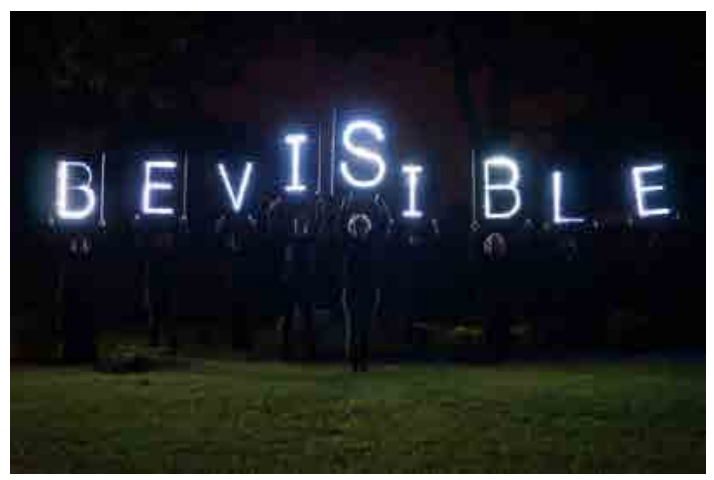

Figura 22.

$\mathrm{Su}$ singularidad radica en el uso de los mismos canales que la mercadotecnia utiliza para persuadir y hacerse visibles: los neones, las letras luminosas, toda esa multifrenia de mensajes que se suceden y se solapan ante los ojos del ciudadano. La misma luminosidad de los neones visibiliza a las grandes marcas corporativas y los mensajes ecologistas y por la igualdad social que muestra este colectivo (fig. 21). Con esta práctica, estos activistas reutilizan el código visual que convierte las ciudades en muestrarios y escaparates estridentemente luminosos. Overpass Light Brigade reciclan este modo de enunciación para hacer que hable con otras voces (fig. 22), tergiversando una forma de decir que los ciudadanos asociábamos con la mercancía. Revisten sus demandas sociales con el vistoso disfraz del consumo, se valen de sus mismos resortes y se expresan con sus mecanismos de mediación social. 


\section{Conclusión}

En resumen, diremos que la piratería publicitaria responde, con los mismos códigos, al tipo de sociedad en la que se inscribe como voz contestataria. Fuera ya del marco panóptico y estabulario, los discursos subversivos tradicionales se ven desarmados. En este nuevo contexto de disolución de los grandes discursos, la contrapublicidad surge con toda su energía catártica precisamente porque se vale de las mismas armas que la sociedad de consumo usa para perpetuar la mercadotecnia. Tomando esta matriz y resignificando la narrativa hegemónica del mercado, éstas y otras muchas intervenciones activistas consiguen reabrir una herida que parecía suturada.

El culture jamming, en sus diversas vertientes y ámbitos de acción, decodifica el lenguaje massmediático y lo vuelve en contra de las multinacionales, revelando la impostura de la ciudad vendida y promocionada como producto. Pone de relieve este vaciamiento ético, evidenciando que esa carencia es el grado cero del consumo.

Estos francotiradores semióticos, a través de la parodia, del doble sentido, del juego de palabras, del chiste, de la sátira, del arte, del collage, etc. construyen un discurso perturbador que produce extrañamiento y abren una reflexión acerca de cómo habitamos la ciudad. La torsión del significante, el reciclaje de esta gramática cultural del mercado, la tergiversación del sentido original de los mensajes publicitarios que saturan el campo visual urbano, apuntan a desnaturalizar el simulacro comercial que se ha adueñado del paisaje urbano y de nuestra forma de interaccionar con nuestras ciudades.

Advertimos, por otra parte, otros modos de ser consumidor. En muchos de los ejemplos señalados, subyace una nueva competencia en el acto de comprar y en todos aquellos elementos que implica esta nueva actancia. En parte, su objetivo es dignificar esta mudanza del campo social desde la plaza pública al centro comercial, lo que supone aceptar esta nueva matriz de convivencia e interacción social.

Vislumbramos en estas prácticas el deseo de una reapropiación del espacio, el reconocimiento de otros modos de vivir el devenir urbano. Se trata, en definitiva, de avivar las ascuas de la ciudad como acontecimiento, como eterna reconstrucción y optimización de sí misma a tiempo real. Celebrar la posibi- 
lidad de todas las ciudades que están por construir. Devolverle a ciudad esa pátina de verdad, ese lustre de vida cotidiana; recuperar el derecho de vivirla y no sólo de transitarla; desvelar el simulacro y retirarle la máscara a la verdadera piel del asfalto. 


\section{Referencias}

Agamben, G. (2000). Lo que queda de Auschwitz. Valencia: Pre-Textos.

Augé, M. (2003). El tiempo en ruinas. Barcelona: Gedisa.

Baudrillard, J. (1978). Cultura y simulacro. Barcelona: Kairós.

Blisset, L., Brunzels, S. y Grupo Autónomo A.F.R.I.K.A. (2000). Manual de guerrilla de la comunicación. Cómo acabar con el mal. Barcelona: Virus.

Cucó Giner, J. (2004). Antropología urbana. Barcelona: Ariel.

Delgado, M. (1998). «Els usos del consum. Àgora i simulacre en els nous centres comercials». Revista d'etnologia de Catalunya, 12, pp. 36-49.

- (2007) Sociedades movedizas. Pasos hacia una antropología de las calles. Barcelona: Anagrama.

García Canclini, N. (1995) Consumidores y ciudadanos: conflictos multiculturales de la globalización. México: Grijalbo.

KLeIn, N. (2011). No logo. El poder de las marcas. Barcelona: Paidós.

LefebVRe, H. (1969). El derecho a la ciudad. Barcelona: Edicions 62.

Lipovetsky, G. (1990). El imperio de lo efimero. La moda y su destino en las sociedades modernas. Barcelona: Anagrama.

- (2003). La era del vacío. Ensayos sobre el individualismo contemporáneo. Barcelona: Anagrama.

LyotaRd, J. F. (2006). La condición postmoderna. Madrid: Cátedra.

SARLO, B. (2010). La ciudad vista. Mercancías y cultura urbana. Buenos Aires: Siglo XXI.

Ulmer, G. L. (1998). «El objeto de la postcrítica». En H. Foster (Coord.). La postmodernidad. Barcelona: Kairós.

Referencia de imágenes

Figura 1: https://eldergaiden.wordpress.com/category/uncategorized/page/6/

Figura 2: http://www.eldiario.es/murcia/cultura/Sam3-Guernica-Osborne-Santa-Pola_0_647086007.html

Figura 3: http://alllies.org/blog/archives/31044

Figura 4: http://dearblogger1234.blogspot.com.es/2010/08/tutespark-week-5. html 
Figura 5: http://www.angelfire.com/rebellion2/wildlife/Wild.htm

Figura 6: https://theafterlifeepitaph.wordpress.com/tag/branding/

Figura 7: http://benedante.blogspot.com.es/2010/07/

Figura 8: https://nuestropensar.wordpress.com/2011/01/27/la-conspiracion-del-tabaco/

Figura 9: http://www.culturematters.org.uk/index.php/culture/theory

Figura 10: https://letsplayinnovation.wordpress.com/2013/03/16/mr-six-andbanana-guy/

Figura 11: http://arteblog13.blogspot.com.es/2010_03_01_archive.html

Figura 12: https://twitter.com/uk_feminista/status/306376247775207424

Figura 13: https://unodeesosdias.wordpress.com/2010/09/27/publicidad-sutil-3/

Figura 14: https://helenaprova.wordpress.com/

Figura 15: http://www.bugaup.org/gallery_1980.htm

Figura 16: https://blog.vandalog.com/2012/07/brandalism-mass-takeover-of-british-billboards/

Figura 17: https://www.spellingmistakescostlives.com/projects

Figura 18: https://actualidadextereo.wordpress.com/category/sin-categoria/ page/78/

Figura 19: http://proyectosquatters.blogspot.com.es/

Figura 20: http://proyectosquatters.blogspot.com.es/

Figura 21: https://www.dailykos.com/story/2014/1/1/1266521/-Overpass-Light-Brigade-2013-A-Year-of-Collaborations-and-Light

Figura 22: https://uaptsd.org/filmthepolice-overpass-light-brigade-3/ 